
\title{
25 Research Square \\ The Effect of Breastfeeding on Photorefractive Keratectomy Outcomes: A Retrospective Cohort Study
}

Siamak Zarei-Ghanavati

Mashhad University of Medical Sciences

Amir Reza Daneshmand Eslami

Mashhad University of Medical Sciences

Alireza Eslampoor

Mashhad University of Medical Sciences

Saeed Shokouhi Rad

Mashhad University of Medical Sciences

Saeed Akhlagi

Mashhad University of Medical Sciences

Mojtaba Abrishami ( $\nabla$ mojtaba_abrishami@yahoo.com )

Mashhad University of Medical Sciences https://orcid.org/0000-0003-2001-7929

Research

Keywords: Breastfeeding, photorefractive keratectomy, refractive surgery, visual function, safety

Posted Date: March 18th, 2020

DOI: https://doi.org/10.21203/rs.3.rs-17691/v1

License: (c) (i) This work is licensed under a Creative Commons Attribution 4.0 International License.

Read Full License 


\section{Abstract}

Purpose To assess the refractive results, visual function, and safety of photorefractive keratectomy (PRK) in myopic breastfeeding women and compare them to healthy matched female controls.

Methods Twelve mothers (23 eyes) who underwent PRK while they were still breastfeeding (B group) and continued it for at least three months participated in this retrospective matched cohort study. Twelve women (23 eyes) who were matched for age, refractive error, and operation data (NB group) were selected as the control group. Post-PRK results and complications were compared between the two groups.

Results Twenty four breastfeeding mothers with a mean age of $29.70 \pm 1.8$ (Standard Deviation) (range from 27 to 33years) were included. The average age in the study and the control group were $29.83 \pm 1.80$ and, $29.58 \pm 1.98$, prospectively, (P-value $=0.749$, T-test, poverty 0.1 ). The mean duration of breastfeeding was 47 weeks before surgery and 35 weeks after surgery.

Conclusion Our study results did not indicate the adverse effects of breastfeeding on the results of PRK surgery. It seems that performing PRK is safe in the breastfeeding period.

\section{Introduction}

Photorefractive keratectomy (PRK) is believed to be a safe and efficacious method of correcting refractive errors. However, all patients who request surgery are not able to have keratorefractive surgery and not recommend in many cases. Many breastfeeding mothers are told that they cannot undergo refractive surgery until their breastfeeding is completed.(1) In previous studies, nursing is considered as one of exclusion criteria.(2) Mothers are usually recommended to wait 3-6 months or longer after termination. Even though a number of women experience visual changes during lactation, we could not find evidence to support the idea that all mothers will experience visual changes or that vision changes that do occur during pregnancy and will usually remain throughout lactation. $(3,4)$ However, many mothers request to have refractive surgery during this period, as they may be in leave due to breastfeeding. In this study, we evaluated the efficacy and safety in the long term follow up of PRK in breastfeeding mothers.

\section{Methods}

\section{Study Population}

Breastfeeding women affected with myopia and myopic astigmatism presenting to the Khatam-al-Anbia Eye Hospital for refractive surgery participated in this study. The inclusion criteria were age of 18-40 years, spherical equivalent (SE) refraction ranging from -1.00 to -8.00 diopters (D) with $3.00 \mathrm{D}$ or less astigmatic error, stable refraction for at least 3 months, and preoperative best-corrected visual acuity (BCVA) of $20 / 20$ or better. 
The exclusion criteria were: any corneal dystrophies or abnormalities, the presence of any ocular pathologic condition that impaired visual function, any previous ocular surgery, keratoconus or keratoconus suspect, glaucoma or glaucoma suspect, auto-immune diseases, diabetes mellitus, moderate to severe dry eye. All patients discontinued contact lens wear at least one month before refraction and topography evaluation.

A detailed ocular examination was performed before surgery including best corrected visual acuity (BCVA), uncorrected visual acuity (UCVA), slit lamp examination, indirect funduscopy, applanation Goldman tonometry, manifest refraction, keratometry (Topcon KR8800Auto-kerato-refractometer, Tokyo, Japan), cycloplegic refraction, TMS-4 topography (Tomey, USA), scanning slit corneal tomography (Orbscan IIz - Bausch \& Lomb, Rochester, NY), and central ultrasound pachymetry. Snellen acuity charts were used to measure UCVA and BCVA. The visual acuities were converted to LogMAR for analysis. Also, corneal haziness was graded by grade $0-4$ and the grade of dry eye was evaluated by the ocular surface 2007 guideline used. ${ }^{4}$ The patients were re-examined on post-operative day 2 , day 5 , month 1 , month 3 and month 6.

\section{Surgical Procedure}

After sterile draping, the cornea was anesthetized with tetracaine $1 \%$ eye drops and an eyelid speculum was inserted. Ethyl alcohol $20 \%$ was subsequently applied in a $9 \mathrm{~mm}$ well for 20 seconds and the epithelium was excised with a hockey stick spatula. Multidimensional rotational eye tracking was applied during the ablation in both groups. The minimum optical zone was $6 \mathrm{~mm}$ and equal optical zone was chosen for both eyes of each patient. Two surgeons (A. E. and S .Z. G.) carried out all surgeries by the use of a flying-spot 193-nm excimer laser (Technolas217z, Bausch \& Lomb, Irvine, USA) with a fixed pulse repetition rate of $100 \mathrm{~Hz}$ and a spot diameter of $1-2 \mathrm{~mm}$. A sponge soaked with mitomycin $\mathrm{C} 0.02 \%$ was applied for all patients over the ablated area for 5 seconds per each diopter of treatment. A bandage contact lens was placed after copious balanced salt solution irrigation of the ocular surface.

Postoperatively, the patients received preservative-free levofloxacin $5 \mathrm{mg} / \mathrm{mL}$ and betamethasone $0.1 \%$ eye drops every $6 \mathrm{~h}$. After complete reepithelialization (usually on the fifth day), the bandage contact lens was taken away. Levofloxacin was discontinued after 1 week. Betamethasone was used for 1 month, and then fluorometholone $0.1 \%$ eye drops were started every $6 \mathrm{~h}$ and gradually tapered over 2 months. Preservative-free artificial tears were administered frequently in the first month and then tapered based on the ocular surface condition.

\section{Postoperative Evaluation}

At the 3-year postoperative visit as preoperative, HOAs, was measured with abberometer under mesopic conditions with a minimum pupil diameter of $6.0 \mathrm{~mm}$. Moreover, root mean square (RMS) values were calculated from Zernike coefficient and reported in micrometers. Additionally, corneal topography parameters, scanning-slit corneal tomography, and refractive and visual outcomes were measured. 


\section{Data Analysis}

All statistical analyses were done using SPSS18 (SPSS Inc. Chicago, Illinois, USA). The differences between the case and control groups were compared using Student t-tests. Scanning-slit corneal tomography, the independent T-test, and the Chi-square statistic were used to analyze and determine continuous variables (age) and categorical variables in the two groups, respectively $(P<0.05)$.

\section{Ethical Considerations}

With respect to the Declaration of Helsinki, the experimental procedures were clarified for the participants and the informed written consent was obtained from each patient. This study was approved by Committee of Ethics in Human Research at Mashhad University of Medical Sciences.

\section{Results}

A total of 24 women with a mean age of $29.70 \pm 1.8$ years (Standard Deviation) (range from 27 to 33 years) took part in the study. The average age in the study and the control group was $29.83 \pm 1.80$ and, $29.58 \pm 1.98$ years, respectively, ( $P$-value $=0.749$, T-test, poverty 0.1$)$. The mean duration of breastfeeding was 47 weeks before surgery and 35 weeks after surgery. Table 1 displays the baseline characteristics. There were no statistically significant differences in UCVA, BCVA, the manifest, and cycloplegic refractions. 
Table 1

Comparison of refractive and visual function parameters of cases before and after photorephractive keratectomy

\begin{tabular}{|c|c|c|c|c|c|c|c|c|}
\hline \multirow{2}{*}{$\begin{array}{l}\text { Parameters ( } \\
\text { Mean } \pm \text { Standard } \\
\text { Deviation) }\end{array}$} & \multicolumn{4}{|c|}{ Before operation } & \multicolumn{4}{|c|}{ After operation } \\
\hline & Cases & Controls & $\begin{array}{l}\text { P } \\
\text { Value* }\end{array}$ & Power & $\begin{array}{l}\text { Study } \\
\text { group }\end{array}$ & Controls & $\begin{array}{l}\mathrm{P} \\
\text { Value }\end{array}$ & Power \\
\hline \multicolumn{9}{|l|}{ Visual Function } \\
\hline UCVA & $\begin{array}{l}0.5 \pm \\
1.54\end{array}$ & $\begin{array}{l}0.5 \pm \\
0.143\end{array}$ & 0.782 & 0.09 & $\begin{array}{l}0.96 \\
\pm \\
0.092\end{array}$ & $\begin{array}{l}0.97 \pm \\
0.045\end{array}$ & 0.827 & 0.1 \\
\hline BCVA & $\begin{array}{l}1.00 \pm \\
0.00\end{array}$ & $\begin{array}{l}1.00 \pm \\
0.00\end{array}$ & & & $\begin{array}{l}1.00 \\
\pm \\
0.00\end{array}$ & $\begin{array}{l}1.00 \pm \\
0.00\end{array}$ & & \\
\hline \multicolumn{9}{|c|}{ Manifest Refraction } \\
\hline Spher (Diopter) & $\begin{array}{l}-3.040 \\
\pm 1.983\end{array}$ & $\begin{array}{l}-3.02 \pm \\
1.703\end{array}$ & 0.398 & 0.5 & $\begin{array}{l}-0.09 \\
\pm \\
0.638\end{array}$ & $\begin{array}{l}-0.2 \pm \\
0.593\end{array}$ & 0.402 & 0.5 \\
\hline Cylindr (Diopter) & $\begin{array}{l}-0.90 \pm \\
0.811\end{array}$ & $\begin{array}{l}-0.93 \pm \\
0.743\end{array}$ & 0.991 & 0.6 & $\begin{array}{l}-0.33 \\
\pm \\
0.372\end{array}$ & $\begin{array}{l}-0.28 \pm \\
0.264\end{array}$ & 0.408 & 0.7 \\
\hline \multicolumn{9}{|c|}{ Cycloplegic Refraction } \\
\hline Spher (Diopter) & $\begin{array}{l}-3.26 \pm \\
1.706\end{array}$ & $\begin{array}{l}-2.96 \pm \\
1.797\end{array}$ & 0.170 & 0.2 & $\begin{array}{l}0.34 \\
\pm \\
0.624\end{array}$ & $\begin{array}{l}0.36 \pm \\
0.605\end{array}$ & 0.022 & 0.95 \\
\hline Cylindr (Diopter) & $\begin{array}{l}-0.95 \pm \\
0.826\end{array}$ & $\begin{array}{l}-0.93 \pm \\
0.815\end{array}$ & 0.278 & 0.07 & $\begin{array}{l}-0.34 \\
\pm \\
0.366\end{array}$ & $\begin{array}{l}-0.26 \pm \\
0.286\end{array}$ & 0.153 & 0.75 \\
\hline
\end{tabular}

Anamnesis morbi did not show suffers from blurry vision. In the study group, UCVA was 0.90 in 6 eyes (26.08\%) and 1.0 in 17 eyes (73.92\%). In the control group, UCVA was 0.7 in one eye (4.35\%), 0.9 in 4 eyes (17.39\%) and 1.0 in 18 eyes (78.26\%). No statistically significant difference was observed in UCVA or BCVA between the two groups (Table 1). The surgical efficacy indices were $96.97 \%$ and $97.3 \%$ in the study and the control group, respectively.

The manifest refractions showed no statistically significant difference in sphere, cylinder, also SE between groups; Furthermore, all patients were slightly myopic (Table 3). MRSE was moderately 
hyperopic and statistically lower in the study group than the control group $(0.35 \pm 0.60$ vs. $0.28 \pm 0.60$, respectively) (P-value $=0.157, \mathrm{GEE})$.

Table 3

Comparison of Orbscan topographic parameters of cases before and after photorephractive keratectomy.

\begin{tabular}{|c|c|c|c|c|c|c|c|c|}
\hline \multirow{3}{*}{$\begin{array}{l}\text { arameter } \\
\text { (Mean } \pm \\
\text { Standard } \\
\text { Deviation) }\end{array}$} & \multicolumn{4}{|c|}{ Before operation } & \multicolumn{4}{|c|}{ After operation } \\
\hline & Cases & Controls & & Power & Cases & Controls & & Powe \\
\hline & & & Value $^{\dagger}$ & & & & Value $^{t}$ & \\
\hline $\begin{array}{l}\text { Pupil Diameter } \\
\text { (mm) }\end{array}$ & $\begin{array}{l}3.99 \pm \\
0.443\end{array}$ & $\begin{array}{l}3.85 \pm \\
0.677\end{array}$ & 0.00 & 0.95 & $\begin{array}{l}3.96 \pm \\
0.61\end{array}$ & $\begin{array}{l}3.65 \pm \\
0.427\end{array}$ & 0.011 & 0.95 \\
\hline CCT $(\mu \mathrm{m})$ & $\begin{array}{l}539.29 \\
\pm \\
28.128\end{array}$ & $\begin{array}{l}537.30 \\
\pm 25.596\end{array}$ & 0.713 & 0.01 & $\begin{array}{l}457.34 \\
\pm 48.87\end{array}$ & $\begin{array}{l}434.54 \\
\pm \\
101.97\end{array}$ & 0.255 & 0.12 \\
\hline $\begin{array}{l}\text { Anterior BFS } \\
\text { (D) }\end{array}$ & $\begin{array}{l}43.65 \pm \\
1.41\end{array}$ & $\begin{array}{l}41.08 \pm \\
7.713\end{array}$ & 0.018 & 0.95 & $\begin{array}{l}42.05 \\
\pm 1.104\end{array}$ & $\begin{array}{l}40.87 \pm \\
0.986\end{array}$ & 0.00 & 0.95 \\
\hline $\begin{array}{l}\text { Posterior BFS } \\
\text { (D) }\end{array}$ & $\begin{array}{l}53.07 \pm \\
1.932\end{array}$ & $\begin{array}{l}51.57 \pm \\
1.637\end{array}$ & 0.00 & 0.95 & $\begin{array}{l}53.06 \\
\pm 1.932\end{array}$ & $\begin{array}{l}51.90 \pm \\
1.738\end{array}$ & 0.030 & 0.95 \\
\hline Sim K's (D) & $\begin{array}{l}-0.85 . \pm \\
1.025\end{array}$ & $\begin{array}{l}-1.07 \pm \\
0.981\end{array}$ & 0.739 & 0.59 & $\begin{array}{l}-0.84 \pm \\
0.361\end{array}$ & $\begin{array}{l}-0.77 \pm \\
0.428\end{array}$ & 0.787 & 0.28 \\
\hline \multicolumn{9}{|l|}{$\begin{array}{l}\text { Sim K } \\
\text { Maximum (D) }\end{array}$} \\
\hline Mean \pm SE & $\begin{array}{l}45.32 \pm \\
1.690\end{array}$ & $\begin{array}{l}44.27 \pm \\
0.985\end{array}$ & 0.026 & 0.95 & $\begin{array}{l}41.90 \\
\pm 1.257\end{array}$ & $\begin{array}{l}40.82 \pm \\
1.387\end{array}$ & 0.567 & 0.46 \\
\hline \multicolumn{9}{|l|}{ SimMn (D) } \\
\hline Mean \pm SE & $\begin{array}{l}44.24 \pm \\
1.407\end{array}$ & $\begin{array}{l}43.07 \pm \\
0.230\end{array}$ & 0.0 & 0.95 & $\begin{array}{l}41.00 \\
\pm 1.21\end{array}$ & $\begin{array}{l}39.95 \pm \\
1.41\end{array}$ & 0.244 & 0.03 \\
\hline \multirow{2}{*}{$\begin{array}{l}\text { Irregular } \\
\text { Astigmatism in } \\
3 \mathrm{~mm} \text { (D) }\end{array}$} & & & & & & & & \\
\hline & $\begin{array}{l}0.96 \pm \\
0.282\end{array}$ & $\begin{array}{l}0.97 \pm \\
0.369\end{array}$ & 0.0 & 0.95 & $\begin{array}{l}1.17 \pm \\
0.345\end{array}$ & $\begin{array}{l}1.19 \pm \\
0.582\end{array}$ & 0.873 & 0.02 \\
\hline $\begin{array}{l}\text { Irregular } \\
\text { Astigmatism in } \\
5 \mathrm{~mm} \text { (D) }\end{array}$ & $\begin{array}{l}1.37 \pm \\
0.260\end{array}$ & $\begin{array}{l}1.243 \pm \\
0.289\end{array}$ & 0.028 & 0.95 & $\begin{array}{l}1.77 \pm \\
0.626\end{array}$ & $\begin{array}{l}1.80 \pm \\
0.616\end{array}$ & 0.611 & 0.04 \\
\hline
\end{tabular}

The biomicroscopy evaluation showed clear corneas in all patients. Seven women (58.3\%) in the study group and 8 women $(66.7 \%)$ in the control group had dry eye complaints. Consequently, preservative-free hydroxypropyl methylcellulose were prescribed and administered $(P=1.0$, poverty $=0.12)$. 
The results of corneal topography such as Surface Regularity Index (SRI) and Surface Asymmetry Index (SAI) are presented in Table 2.

\section{Table 2}

Comparison of placido topographic parameters of cases before and after photorephractive keratectomy.

\begin{tabular}{|c|c|c|c|c|c|c|c|c|}
\hline \multirow{2}{*}{$\begin{array}{l}\text { Parameters (Mean } \\
\pm \text { Standard } \\
\text { Deviation) }\end{array}$} & \multicolumn{4}{|c|}{ Before operation } & \multicolumn{4}{|c|}{ After operation } \\
\hline & Cases & Controls & $\begin{array}{l}P \\
\text { Value }^{\dagger}\end{array}$ & Power & Cases & Controls & $\begin{array}{l}\text { P } \\
\text { Value }^{+}\end{array}$ & Power \\
\hline Cylinder (D) & $\begin{array}{l}0.10 \pm \\
0.73\end{array}$ & $\begin{array}{l}1.27 \pm \\
0.720\end{array}$ & 0.747 & 0.01 & $\begin{array}{l}0.91 \\
\pm \\
0.414\end{array}$ & $\begin{array}{l}0.88 \pm \\
0.434\end{array}$ & 0.006 & 0.95 \\
\hline $\begin{array}{l}\text { Surface regularity } \\
\text { index (SRI) }\end{array}$ & $\begin{array}{l}0.19 \pm \\
0.16\end{array}$ & $\begin{array}{l}0.15 \pm \\
0.131\end{array}$ & 0.138 & 0.11 & $\begin{array}{l}0.08 \\
\pm 0.05\end{array}$ & $\begin{array}{l}0.08 \pm \\
0.046\end{array}$ & 0.510 & 0.01 \\
\hline $\begin{array}{l}\text { Surface } \\
\text { Asymmetry Index } \\
\text { (SAl) }\end{array}$ & $\begin{array}{l}0.33 \pm \\
1.171\end{array}$ & $\begin{array}{l}0.26 \pm \\
0.088\end{array}$ & 0.093 & 0.19 & $\begin{array}{l}0.33 \\
\pm \\
0.107\end{array}$ & $\begin{array}{l}0.31 \pm \\
0.175\end{array}$ & 0.840 & 0.02 \\
\hline
\end{tabular}

The best fit surfaces, their minimum and maximum, the mean of Sim K's, the mean of irregular astigmatism, and central corneal thickness (CCT) were measured and provided in Table 3.

The distribution of various HOAs, RMS of total HAOs, and spherical aberrations were computed and given in Table 4). 
Table 4

Comparison of aberrometric parameters of cases before and after photorephractive keratectomy.

\section{Parameter}

Before operation

Study Control P

group Group Value ${ }^{\dagger}$
After operation

Poverty Study Control P

group Group Value $^{\dagger}$

Poverty

HOAs in $5.0 \mathrm{~mm}$

$(\mu \mathrm{m})$

$\begin{array}{lllllllll}\text { Mean } \pm \text { SE } & 0.21 & 0.21 \pm & 0.00 & 0.95 & 0.24 & 0.24 \pm & 0.731 & 0.01 \\ & \pm & 0.068 & & & \pm & 0.082 & & \\ & 0.055 & & & & 0.087 & & & \end{array}$

RMS of HOAS

without SA Z $(4,0)$

in $5.0(\mu \mathrm{m})$

Mean \pm SE

$\begin{array}{llll}0.19 & 0.19 \pm & 0.354 & 0.01 \\ \pm 0.05 & 0.07 & & \end{array}$

0.21

$0.23 \pm$

0.798

0.03

$\pm .082$

0.738

Total HOAs in

$5.0 \mathrm{~mm}(\mu \mathrm{m})$

Mean \pm SE

$\begin{array}{ll}3.45 & 3.22 \pm \\ \pm 1.65 & 1.68\end{array}$

$0.067 \quad 0.34$

0.59

$\pm$

0.239

$0.69 \pm$

0.430

0.53

0.236

HOAs in $6.0 \mathrm{~mm}$

( $\mu \mathrm{m})$

Mean \pm SE

$\begin{array}{llllllll}0.35 & 0.32 \pm & 0.953 & 0.55 & 0.45 & 0.42 \pm & 0.382 & 0.02 \\ \pm 0.09 & 0.09 & & & \pm & 0.161 & & \\ & & & & 0.170 & & & \end{array}$

RMS of HOAs

without SA Z $(4,0)$

in $6.0(\mu \mathrm{m})$

Mean \pm SE

$\begin{array}{ll}0.29 & 0.29 \pm \\ \pm 0.11 & 0.10\end{array}$

0.796

0.01

0.39

$0.38 \pm$

$\pm$

0.148

0.394

0.01

0.147

Total HOAs in

$6.0 \mathrm{~mm}(\mu \mathrm{m})$

Mean \pm SE

$\begin{array}{llll}4.94 & 4.35 \pm & 0.480 & 0.3\end{array}$

2.19

0.96

$1.05 \pm$

0.173

0.33

$\pm 2.44 \quad 2.19$

$\pm$

0.44 


\begin{tabular}{|c|c|c|c|c|c|c|c|c|}
\hline \multirow[t]{2}{*}{ Parameter } & \multicolumn{4}{|c|}{ Before operation } & \multicolumn{4}{|c|}{ After operation } \\
\hline & $\begin{array}{l}\text { Study } \\
\text { group }\end{array}$ & $\begin{array}{l}\text { Control } \\
\text { Group }\end{array}$ & $\begin{array}{l}\text { P } \\
\text { Value }^{\dagger}\end{array}$ & Poverty & $\begin{array}{l}\text { Study } \\
\text { group }\end{array}$ & $\begin{array}{l}\text { Control } \\
\text { Group }\end{array}$ & $\begin{array}{l}P \\
\text { Value }^{\dagger}\end{array}$ & Poverty \\
\hline \multicolumn{9}{|c|}{$\begin{array}{l}\text { SE = standard error; } \\
\text { HOAs = root mean square of higher-order aberrations; } \\
\text { RMS = root mean square; } \\
\text { SA = spherical aberration. }\end{array}$} \\
\hline
\end{tabular}

\section{Discussion}

During normal pregnancy, hormonal, metabolic, hematological, vascular, and immunological changes can be observed (9), which can be shown to be associated with ocular changes during pregnancy. These changes include increased curvature as well as steepness of the cornea that begin during pregnancy, continue during breastfeeding, and returns to the original status with the end of breastfeeding (13). A slight increase in the thickness of the cornea at the end of the pregnancy period associated with changes in refraction and compliance can continue during breastfeeding $(14,15)$. Another change is the reversible reduction in tear film as a result of the prolactin secretion increase during pregnancy and breastfeeding (16). Therefore, refractive surgery is not usually recommended during pregnancy and a year after childbirth $(17,18)$.

However, pregnancy and breastfeeding have some differences in physiological changes, which could affect results of the laser vision correction (LVC). One of these differences is the physiological changes associated with the role of placenta during pregnancy. During pregnancy, as an endocrine system, the placenta is independently capable of producing cytokines and hormones. The placenta cytokines are tumor necrosis factor alpha-TNFa, Resistin, and leptin. The important hormones of the placenta are human chorionic somatomammotropin-HCS, cortisol, estrogen, progesterone, and human placental growth hormone -HPG (19-21). TNFa potentially plays a role in physiological dosages in causing corneal scars followed by corneal opacity after PRK (22). Meanwhile, in the normal people (non-pregnant and non-breastfeeding women), a natural increase in TNFa is observed at physiological levels on the first two days after PRK, which plays an important role in improving the corneal ulcer followed by laser ablation (23). In a study by Jiang, it was suggested that Resistin can increase the local cytokines and exacerbate inflammatory reaction by inducing extracellular leukocytosis (24). Prolactin effects has been examined on the production of tears and it has been specified that there is a negative relationship between serum prolactin and tear secretion, but a positive relationship has been observed between estradiol and tear secretion among women aged 30-39 years (25). It can be noted that during breastfeeding, the most important effective factor for the visual organ, which probably affects the results of PRK surgery is the prolactin hormone. Hence, the hormonal profile of pregnancy period is distinguished from breastfeeding with placenta and further production of prolactin and all types of cytokines as well as 
other hormonal changes in other glands of the body; thus, classifying pregnancy and breastfeeding in one group regarding the possibility of PRK surgery is not very reasonably justifiable.

In our study, postoperatively, comparison of the two groups showed no statistically significant differences in terms of corneal opacity, dry eye, UCVA, BCVA, dry and cycloplegic refraction (except for cylinder). In this regard, the coefficient of surgical effect in the two groups was in the range of the previous studies (26).

\section{Visual Acuity}

In comparing the uncorrected visual acuity, the two groups of breastfeeding and non-breastfeeding had no statistically significant differences (Table 1). Ghoreishi et al showed that the UCVA of 20/20 and $20 / 40$ and more was observed in $92.1 \%$ and $99.2 \%$ of patients and, after a year, $69.4 \%$ and $91 \%$ of the patients had the entropy of 0.5 and 1.0 diopter (27). Similar results were obtained in the study by Hashemi et al. using MMC during PRK surgery, in which $77.1 \%$ of the eyes had uncorrected visual acuity of $20 / 20$ or better $(28)$.

In the study by Hashemi et al. (2015), after performing PRK using MMC on 30 eyes, the surgery impact factor was 1.01 (26). In the present study, although the MMC was not used in all of the patients, the results of the surgery impact factor were lower than the previous results.

\section{Spherical Equivalent}

In most of the studies, the values of manifest refraction spherical equivalent (MRSE) are in the range of mild myopia after PRK surgery $(29,30)$, but the mean of MRSE can also be found in the range of mild hyperopia which, for instance, can be seen in the report by Randelman et al. (2009) (31). In the upcoming study, in both groups, the general overview of the average post-operative results of MRSE was shifted towards hyperopia; nevertheless, their comparison showed no statistically significant difference.

\section{Dry Eye}

Dry eye naturally occurs during pregnancy. It is improved by the end of breastfeeding as the level of prolactin decreases $(8,20)$. Besides, the incidence of dry eye could remain on the mild to moderate myopic eyes for 12 years after PRK surgery (32).

In our study, the absence of statistically significant difference in the incidence of dry eye among breastfeeding and non-breastfeeding women was not consistent with the comments of Umti et al. (8). Therefore, along with the effect of prolactin on dry eye, the other cases including meibomian gland dysfunction (MGD) have been also probably effective. 
A slight increase in surface regularity index (SRI) and surface asymmetry index (SAI), higher level of best spherical anterior and posterior surfaces, more severe astigmatism in $5 \mathrm{~mm}$, and a slight increase in HOAs in $5.0 \mathrm{~mm}$ were found before surgery in the breastfeeding group. These changes can be justified despite the edema remaining in the cornea from the pregnancy period $(14,15)$ one result of which can be an increase in the curvature of the cornea (13). However, edema occurs further in marginal areas with thicker stroma (36). The comparison of breastfeeding and non-breastfeeding groups showed no statistically significant difference in terms of the above mentioned items after surgery. Since the laser ablation was performed in the corneal center for myopia correction in which it had smaller diameter than the margin and, consequently, less edema, therefore, physiological changes after pregnancy might have a lower effect on the post-operative results. Furthermore, during the ablation of the corneal center, the laser beams collided at the corneal surface at the $90^{\circ}$ angle, which had a greater penetration impact, while the marginal rays that reached the marginal points of the cornea collided the points with a greater angle to cornea surface and would have less tissue evaporation when the optic area was about $6.5 \mathrm{~mm}$ (37). Probably, fewer changes in the cornea caused by ablation in these areas associated with further edema had less inappropriate results over time with the improvement of edema after pregnancy that continued up to one year later (9). The absence of a significant difference in the comparison of the mean of the lowest corneal thickness between the two groups of breastfeeding and non-breastfeeding women after surgery could justify these cases. Anyway, it was in the range of previous studies (29).

Comparing subjective results and other evaluations including lowest corneal thickness and best anterior spherical surface to the best posterior spherical surface ratio between the two groups three years after the surgery demonstrated no statistically significant difference and were in an optimal level. From the ectasia risk factors mentioned in the previous study (38) and according to the results of Orbscan, there was probably an increase in the slope of cornea in the breastfeeding group in a stage before surgery, but these changes did not result in an even mild keratoconus.

Other factors include the ectasia risk, severe myopia correction, remaining post-ablation thin stromal thickness (39), extensive surface of ablation, irregular corneal thickness, and abnormal corneal topography $(40,41)$. The surgery was carried out in a time interval of 11 months and 1 week after childbirth, and the average duration of breastfeeding was 8 months and 1 week. This can be associated with a decline in the natural complications of pregnancy in the visual organ, especially the cornea, (13$15)$, which is among other reasons that can be effective in preventing ectasia in the breastfeeding women.

\section{Conclusion}

Th results of this study did not indicate any adverse effects of breastfeeding on the results of PRK surgery. Since the average interval from the childbirth was 11 months and 1 week (at least 6 weeks) before PRK surgery, an earlier PRK surgery after childbirth requires further studies and cautious aspects. It should be noted that the success of the surgeries was probably due to the use of mitomycin $\mathrm{C}$ and spherical technique in the PRK surgery. Finally, considering the age range of 27-33 years, and 
mild/moderate myopia and regular moderate astigmatism can be the reason for the success of PRK surgery in the refractive correction of breastfeeding women.

Nevertheless, there were a number of constraints in collecting the required items for this study. Therefore, the results of this study indicate the possibility of choosing the refractive correction method of PRK surgery for women during breastfeeding period. Since no similar study has been carried out in this regard, this research has opened the way to continue the studies on the breastfeeding and laser refractive surgery. For example, the retrospective research project on the patients of this study and also a research with more individuals in the future can be advised.

\section{Declarations}

Availability of data and material: The datasets used and analyzed during the current study are available from the corresponding author on reasonable request.

Competing interests: The authors declare that they have no competing interests

Consent for publication: Not applicable, a retrospective cohort study. We had a general consent for using refractive surgeries patient's data anonymously for any research or publication.

Funding: The authors would like to acknowledge the financial support of Vice-Presidency of Mashhad University of Medical Sciences for this research project research, as thesis of Dr. Amir Reza Daneshmand Eslami (grant Number P8747).

Authors' contributions: All the authors contributed significantly to this research, and all authors agree to be accountable for all aspects of the work. SZG, AE, SSR participated in study conceptualization, design, and in gathering the patients, and performing PRKs. SA participated in statistical analysis and interpretation. ARDE and MA participated in acquisition of clinical data and revising and finalizing the manuscript. All authors read and approved the final manuscript.

Acknowledgement: We would like to thank Pardis Eghbali B.Sc, Elahe Mansourian B.Sc. , Maryam Kadkhoda B.Sc. and Jalil Rahimi B.Sc for their kind assistance with patients' optometric and imaging evaluations.

Ethics approval and consent to participate: All the included subjects were completely notified about the study protocol, and signed the written informed consent; otherwise the participants with disinclination were excluded.

\section{References}

1. Bower KS, Woreta F. Update on contraindications for laser-assisted in situ keratomileusis and photorefractive keratectomy. Curr Opin Ophthalmol. 2014 Jul;25(4):251-7. 
2. Zarei-Ghanavati S, Gharaee H, Hamilton DR, Sanchez PJ, Abrishami M. Aspheric versus wavefrontguided photorefractive keratectomy: contralateral eye study. J Cataract Refract Surg. 2015 Jul;41(7):1441-7.

3. Nkiru ZN, Obiekwe O, Lilian O, Daniel CN, Uchenna IN, Rich U. Visual acuity and refractive changes among pregnant women in Enugu, Southeast Nigeria. J Family Med Prim Care. 2018 SepOct;7(5):1037-1041.

4. Ebeigbe JA, Ebeigbe PN, Ighoroje A. Ocular changes in pregnant Nigerian women. Niger J Clin Pract. 2012 Jul-Sep;15(3):298-301.

5. Behrens A, Doyle JJ, Stern L, Chuck RS, McDonnell PJ, Azar DT, et al. Dysfunctional tear syndrome study group. Dysfunctional tear syndrome: a Delphi approach to treatment recommendations. Cornea. 2006 Sep;25(8):900-7.

9. Kubica-Trazaska A, Karska-Basta I, Kobylarz J, Romanowska-Dixon B. Pregnancy and the eye. Klin Oczna. 2008;110(10-12):401-404. [Polish].

10. Kim JM, Kim JC, Park WC, Seo JS, Chang HR. Effect of thermal preconditioning before excimer laser photoablation. J Korean Med Sci. 2004 Jun;19(3):437-46. doi: 10.3346/jkms.2004.19.3.437.

11. Behrens A, Doyle JJ, Stern L, Chuck RS, McDonnell PJ, Azar DT, et al. Dysfunctional tear syndrome study group. Dysfunctional tear syndrome: a Delphi approach to treatment recommendations. Cornea. 2006 Sep;25(8):900-7.

12. Sharif K. Regression of myopia by pregnancy after photorefractive keratectomy. J Refract Surg. 1997 Aug;13(5):445-6. doi: 10.3928/1081-597X-19970801-13.

13. Park SB, Lindahl KJ, Temnycky GO, Aquavella JV. The effect of pregnancy on corneal curvature. CLAO J. 1992 Oct;18(4):256-9.

14. Weinreb RN, Lu A, Beeson C. Maternal corneal thickness during pregnancy. Am J Ophthalmol. 1988 Mar 15;105(3):258-60.

15. Fatt I, Harris MG. Refractive index of the cornea as a function of its thickness. Am J Optom Arch Am Acad Optom. 1973 May;50(5):383-6.

16. Schechter JE, Pidgeon M, Chang D, Fong YC, Trousdale MD, Chang N. Potential role of disrupted lacrimal acinar cells in dry eye during pregnancy. Adv Exp Med Biol. 2002;506(Pt A):153-7.

17. Dinn RB, Harris A, Marcus PS. Ocular changes in pregnancy. Obstet Gynecol Surv. 2003 Feb;58(2):137-44. doi: 10.1097/01.0GX.0000047741.79433.52.

18. Mackensen F, Paulus WE, Max R, Ness Ocular changes during pregnancy. Dtsch Arztebl Int. 2014 Aug; 111(33-34): 567-576. doi: 10.3238/arztebl.2014.0567.

19. Metzger BE, Buchanan TA, Coustan DR, de Leiva A, Dunger DB, Hadden DR, et al. Summary and recommendations of the Fifth International Workshop-Conference on Gestational Diabetes Mellitus. Diabetes Care. 2007 Jul;30 Suppl 2:S251-60. doi: 10.2337/dc07-s225.

20. Buchanan TA, Xiang A, Watanabe R. What is gestational diabetes? Diabetes Care. 2007 Jul;30 Suppl 2:S105-11. doi: $10.2337 / \mathrm{dc07}-\mathrm{s} 201$. 
21. Buchanan TA, Xiang AH. Gestational diabetes mellitus. J Clin Invest. 2005 Mar;115(3):485-91.

22. Castagnoli C, Stella M, Berthod C, Magliacani G, Richiardi PM. TNF production and hypertrophic scarring. Cellular immunology. 1993;147(1): 51-63. doi: org/10.1006/cimm.1993.1047.

23. Vesaluoma M, Teppo AM, Grönhagen-Riska C, Tervo T. Increased release of tumour necrosis factor-a in human tear fluid after excimer laser induced corneal wound. Br J Ophthalmol. 1997 Feb; 81(2): 145-49.

24. Jiang S, Park DW, Tadie JM, Gregoire M, Deshane J, Pittet JF, et al. Human resistin promotes neutrophil proinflammatory activation and neutrophil extracellular trap formation and increases severity of acute lung injury. J Immunol. 2014 May 15;192(10):4795-803. doi: 10.4049/jimmunol.1302764.

25. Mathers WD, Stovall D, Lane JA, Zimmerman MB, Johnson S. Menopause and tear function: the influence of prolactin and sex hormones on human tear production. Cornea. 1998 Jul;17(4):353-8.

26. Hashemi H, Miraftab M, Asgari S. Photorefractive keratectomy results in myopic patients with thin cornea eyes. Oman J Ophthalmol. 2015 Jan-Apr;8(1):24-7. doi: 10.4103/0974-620X.149860.

27. Ghoreishi M, Attarzadeh H, Zandi A, Moini HA, Tavakoli M, Fesharaki H, et al. Outcomes of photorefractive keratectomy with intraoperative mitomycin-C J Ophthalmic Vis Res. 2009 Jul;4(3):142-46.

28. Hashemi H, Taheri MR, Fotouhi A, Kheiltash Evaluation of the prophylactic use of mitomycin-C to inhibit haze formation after photorefractive keratectomy in high myopia: a prospective clinical study. BMC Ophthalmol. 2004;4:12. doi: 10.1186/1471-2415-4-12.

29. Tomás-Juan J, Murueta-Goyena Larrañaga A, Hanneken L. Corneal Regeneration After Photorefractive Keratectomy: A Review. J Optom. 2015 Jul-Sep;8(3):149-69. doi: 10.1016/j.optom.2014.09.001.

30. Zarei-Ghanavati S, Gharaee H, Hamilton DR, Sanchez PJ, Abrishami M. Aspheric versus wavefrontguided photorefractive keratectomy: contralateral eye study. J Cataract Refract Surg. 2015 Jul;41(7):1441-7. doi: 10.1016/j.jcrs.2014.10.038.

31. Randleman JB, Perez-Seraziota CE, Hu MH, White AJ, Loft ES, Stulting RD. Higher order aberration after wavefront-optimized photorefractive keratectomy and laser in situ keratomileusis. J Cataract Refract Surg. 2009 Feb; 35(2): 260-64. doi: 10.1016/j.jcrs.2008.10.032.

32. Rajan MS, Jaycock P, O'Brart D, Nystrom HH, Marshall J. A long-term study of photorefractive keratectomy; 12-year follow-up. Ophthalmology. 2004 Oct;111(10):1813-24. doi: 10.1016/j.ophtha.2004.05.019.

33. Stephenson CG, Gartry DS, O'Brart DP, Kerr-Muir MG. Marshall J. Photorefractive keratectomy. A 6year follow-up study. Ophthalmology. 1998;105(2):273-81.

34. Shogaie A, Ramazanzadeh M, Soleyman-Jahi S, Almasi-Nasrabadi M, Rezazadeh P, Eslaniu M. Shorttime mitomycin-C during photorefractive keratectomy in patient with low myopia. J Cataract Refract Surg. 2013,39(2):197-203. doi: org/10.1016/j.jcrs.2012.09.016. 
35. Shalaby A, Kaye GB, Gimbel HV. Mitomycin C in photorefractive keratectomy. J Refract Surg. 2009 Jan;25(1):S93-7.

36. Martola EL, Baum JL. Central and peripheral corneal thickness. A clinical study. Arch Ophthalmol. 1968;79(1):28-30. doi:10.1001/archopht.1968.03850040030009.

37. Mrochen M1, Donitzky C, Wüllner C, Löffler J. Wavefront-optimized ablation profiles: theoretical background. J Cataract Refract Surg. 2004 Apr;30(4):775-85. doi: 10.1016/j.jcrs.2004.01.026.

38. Tatar MG, Kantarci FA, Yildirim A, Uslu H, Colak HN, Goker H. Risk factors in post-LASIK corneal ectasia. J Ophthalmol. 2014; 2014: 204191. doi.org/10.1155/2014/204191.

39. Randleman JB, Russell B, Ward MA, Thompson KP, Stulting RD. Risk factors and prognosis for corneal ectasia after LASIK. Ophthalmology. 2003 Feb;110(2):267-75. doi: 10.1016/S01616420(02)01727-X.

40. Jacobs JM, Taravella MJ. Incidence of intraoperative flap complications in laser in situ keratomileusis. J Cataract Refract Surg. 2002;28(1):23-8.

41. Combish IF, Lawless MA. Progressive post-LASIK keratectasia: biomechanical instability or chronic disease process? J Cataract Refract Surg. 2002;28(12):2206-13. 